Maciej Bernasiewicz

ORCID 0000-0001-6636-5377

MARCIN GIERCZYK

ORCID 0000-0001-6734-2521

Uniwersytet Śląski w Katowicach

\title{
FAMILY-SCHOOL-PARTNERSHIP ABOUT VIRTUE DEVELOPMENT
}

\begin{abstract}
Aвstract. Bernasiewicz Maciej, Gierczyk Marcin, Family-School-Partnership About Virtue Development [Partnerstwo rodziny i szkoły dla rozwoju cnót]. Studia Edukacyjne nr 52, 2019, Poznań 2019, pp. 127138. Adam Mickiewicz University Press. ISSN 1233-6688. DOI: 10.14746/se.2019.52.9

Many types of research appear to show that communication barriers and a bad relationship between teachers and parents can hinder the development of behavioral skills and cognitive capacities that enable some individuals to put their moral habits into their life. Teachers' and parents' common aim is to create in young people attitudes consistent with the given system of values. This article is a theoretical overview of the issues related to the family-school partnership about Virtue Development, on the basis of which the authors proposed a conceptual model of an interdependent and interrelated relationship between teachers and parents and demonstrated how the inclusion of parents, students and teachers in broadly understood activities for the benefit of others (people, animals, nature, etc.) is particularly valuable from the point of view of moral development in Polish schools.
\end{abstract}

Key words: parents-teachers partnership, Virtue Development, moral virtues

\section{Introduction}

It can be stated without hesitation that the reflection on the role of school and family in building moral attitudes is timeless. Over the centuries different philosophical and pedagogical systems recognise the importance of the issue and carrying on doing so. One of the explicitly evolving directions of change is the increase of parental involvement in the creation of school realities for the development of students' character and virtue development. Moral development requires coherent interactions. Considering school and 
a family role and their impact on personality and virtue development we cannot forget about the appropriate partnership between teachers' and parents'. First of all, in the area of balancing the influence of popular culture and new media. Tomas Lickona observed that when school included parents in character-building, it enhanced their chance of success with students.

Also, appropriate collaboration with parents allows setting a goal in education and teaching and consistently aiming to achieve virtue development. For many decades, attention has been paid to the fact that both parents and teachers experience the need to work together for the good of their children. Parents believe that it is a teacher's role to encourage good morals and values in a student. Also, it is hard to nurture virtues such as honesty, compassion and courage in school if those are neglected at home. Facilitation of moral development cannot be expected from popular culture, which trivialises all values, promotes hedonistic and neoliberal orientation (draining identity from all problems and existential questions) and creates narcissistic, fluid and apolitical identity deprived of an identity core. Hence the importance of family home and school in promoting activities for other people, especially those whom Zygmunt Baumancalls expendable people for whom we can recognise homeless, unemployed, poor, orphans, immigrants and those who are precarious. In the pursuit of individual success, today's man loses the sense of solidarity with socially excluded people. This tendency is strengthened by mass media and programs that encourage people to promote themselves. They are based on the human need for visibility, or even contemporary obsession with it, which makes us avoid vegetation in a state of frightening and unbearable anonymity. On the other hand, there is a need to watch others (social voyeurism) which is best evidenced by the former television program "Big Brother" and today's inclusion of several billion people in publishing on Facebook or Instagram.

It is necessary for the family and school to promote activities that would be a counterbalance to consumer culture, in which only personal pleasure and well-being count. They will work stronger when cooperating with each other. The article focuses on the fields of cooperation between the school and parents and the benefits resulting from it, and demonstrating how the inclusion of parents, students and teachers in broadly understood activities for the benefit of others (people, animals, nature, etc.) is particularly valuable from the point of view of moral development in Polish schools.

\section{Benefits of Family-School-Partnership}

As set out in the Jubilee Centre's new Framework for Character Education in Schools: 
The development of children's characters is an obligation we all share, not least parents [...] especially children's teachers.

Moreover, in the preamble of the Charter of the Rights and Responsibilities of Parents in Europe,

Raising children is a sign of hope. It shows that people have hope for the future and faith in the values they pass on to the next generation. Therefore, the responsibility of parents for their children is an irreplaceable cornerstone of society. Parents need not stand alone in bearing this responsibility, neither in the Europe of today nor that of tomorrow. The education community helps them with this task, social groups and institutions support them, public services offer material assistance and expertise.

These above words express the essence of the cooperation between parents and teachers. A school is a place where different people communicate and interact. Everyone can exchange views and work together, primarily parents and educators. Parents at school are as important as teachers. A school which realises that parental interaction is necessary for helping for students to succeed and shape their character is simply a school of values, and this benefits not only the child but also the parents and teachers. Well organised cooperation helps with teachers work and is also fulfilling for parents. They feel that they can contribute to the creation of a friendly school environment, which enable students to become good persons and citizens, able to lead a good life as well as become 'successful' person. Family and school (widely understood) are two of the child's educational environments that has the biggest influence on the children's character so there is a need for good relationship and cooperation between teachers and parents.

The collaboration allows us to create a consistent, safe and friendly environment for education and upbringing for all children and to care about their proper and harmonious development both physically and morally. However, for such support, it may be necessary to communicate openly and agree on common goals and plan actions. Communication between the teacher and parent should not be a one-sided process. It is therefore important to acquire both the ability to speak to the mother and father or a guardian. It consists of showing the respect, acceptance and warmth to the interlocutor. Effective communication and the school ethos are essential to create strong teacher-patents partnerships and to increase parental involvement.

The literature consistently shows that:

- although not all parents take the same amount of interest in their children's education, most appreciate being in the loop. I kept them in the loop by 
doing a few simple things at the beginning of the school year and following up from time to time;

- teachers who reported more frequent meetings with parents showed increasing moral vitality scores. Many also remarked that parents need character education and expressed their hopes for greater involvement from parents;

- schools that commit to partnering with parents while focusing on a determined pursuit of positive culture and climate exhibit the kinds of caring and respectful environments that promote academic excellence, healthy relationships, reduced antisocial behaviours, and improved school safety;

- teachers are called to strengthen their relational skills to sustain positive interaction with families;

- when parents and teachers coalesce to create continuities between home and school, children's achievement, social functioning, and emotional adjustment benefit;

- high-quality relationships between parents and teachers foreshadow children's enhanced academic and social-emotional adjustment;

- in the context of children's behavioural concerns, relationships between parents and teachers may become strained;

- parent involvement in education benefits not only the child but also the parents and teachers;

- many parents today aren't fulfilling their primary role in character formation. Regardless of the reality, however, the school should set forth-and work toward-the home-school relationship as it should be: The family lays down the foundation, and the school builds on that base;

- teacher-family communication immediately increased student engagement as measured by homework completion rates, on-task behaviour, and class participation;

As we can see, research appears to show that communication barriers and a bad relationship between teachers and parents can hinder the development of behavioural skills and cognitive capacities that enable some individuals to put their moral habits into their life. There is evidence behind it which tells us to eliminate communication barriers for the proper collaboration between teacher and parent, which translate into appropriate moral development in students.

\section{A Model of Relationship Between Teachers and Parents}

The research literature shows a clear and positive correlation between teacher patents relationship and virtue development. Also, there is a good deal 
of evidence of the link between teacher patents relationship and behaviour (and attitudes to learning) in schools, and grade attainment. Based on the literary analysis we have created an overall conceptual model of an interdependent and interrelated relationship between educators and relatives regarding character education as below:

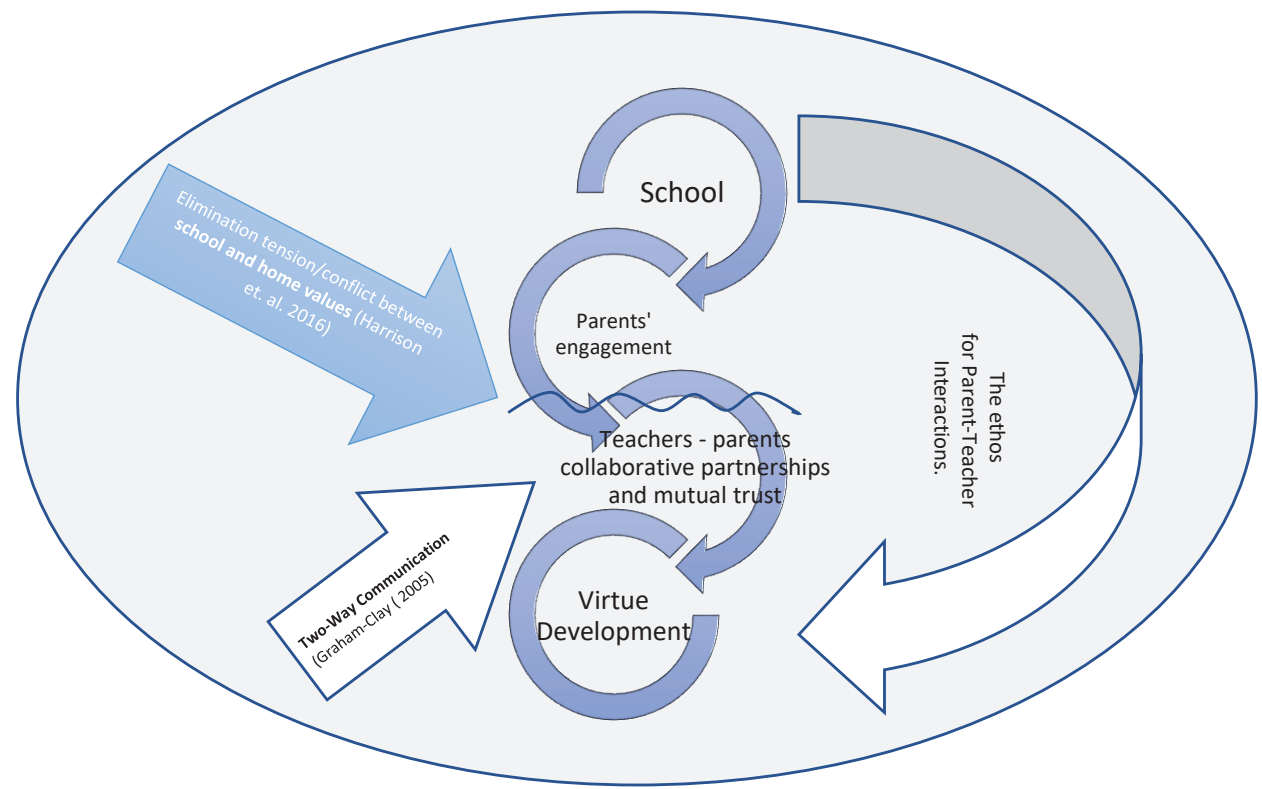

Fig. 1. Conceptual model of the interdependent and interrelated relationship between teachers and parents ${ }^{1}$

The individual elements of the above scheme can be characterised as follows:

- parents' engagement. The engagement is what the school (teachers) would expect from parents and parents from school. Research has shown that parent engagement in Virtue Development at school and home benefits not only the child but also the parents and teachers. ${ }^{2}$ Supporting teachers by parents and parents by teachers is about cooperation and collaborative support. Such sup-

${ }^{1}$ Limitation: This model of the interdependent and interrelated relationship between teachers and parents is only conceptual and based on the empirical research and literary findings and does not exhaust the whole issue.

${ }^{2}$ D. Eldridge, Parent Involvement: It's Worth the Effort. 
port is based on mutual trust, loyalty, and subordination to a goal that must be well-informed by both parents and teachers;

- the school ethos for parent-teacher interaction. The ethos in and around schools must be conducive for parents and teachers to establish healthy relationships. The research evidence is clear: schools that are values-driven have high expectations and demonstrate academic, professional and social success. Because the ethos of a school is the expression of the collective character of everyone, it is important for every member of a school community to have some basic understanding of what character is; ${ }^{3}$

- virtue development. The development of character empowers students and is liberating. ${ }^{4}$ Well-organized teacher's - parent's collaborative partnerships and mutual trust can provide powerful contexts for the teaching and learning of good moral habits;

- elimination of tension/conflict between school and home values. The school operates by socially accepted norms and values. However, the system of these rules and values can very much deviate from those preferred by parents, which can cause some tensions and conflicts, which in turn can negatively affect the relationship and cooperation between the parents and teachers. ${ }^{5}$

Family-school partnership regarding education and virtue development refers us to the concept of morality and moral development. Morality is neither the internalisation of established cultural values nor the development of spontaneous impulses and emotions. It is justice, reciprocity between the individual and other people in its social environment. ${ }^{6}$ The authors of the above definition, though, separate themselves from identifying morality with the value system, but in the second sentence, they refer to justice and reciprocity, which are an example of the value with a universal character. The relativity of all worldviews is often emphasised by postmodernism but justice, solidarity and reciprocity are among the few cultural goals that have remained in postmodern reality. Without going into the consideration of the legitimacy of postmodern doubt in the existence of universal moral codes that could be a common axiological horizon for humanity, we can agree that the content of the moral attitude, which Kohlberg and Mayer write about, are qualities that we would like to pass on to the next generations.

Józef Życiński accurately notes that even postmodernists assume the suprasystem character of certain values and give proof of this in the form of

${ }^{3}$ The Jubilee Centre for Character and Virtue: 'A Framework for Character Education', p. 9.

${ }^{4}$ Ibidem.

5 T. Harrison, I. Morris, J. Ryan, Teaching Character in the Primary Classroom, p. 36.

${ }^{6}$ L. Kohlberg, R. Mayer, Development as the Aim of Education, Harvard Educational Review, 1972, 42(4), p. 449-496. 
views of two thinkers who are advocates of postmodern thinking. Zygmunt Bauman, who treated tolerance, and solidarity as absolute values, and JeanFrançois Lyotard, who maintained that social justice as a universal value. ${ }^{7}$ Solidarity and social sensitivity, as well as tolerance, can be a good horizon for school and family, aiming at the moral development of students. Such defined cultural goals arouse consensus, which is hard to come by in a multicultural and multi-ethnic society.

\section{Family-School Cooperation Fields in Poland}

The basic platform for cooperation between the school and parents in Poland is the parents' council, whose activity is regulated by the Polish education law. ${ }^{8}$ This law stipulates that the competence of the parents' council includes, among others: a) requesting the school head or body and supervising the school with motions and opinions on all school-related matters; b) passing (annually) together with the teachers of the preventive and educational program in force at school; c) giving opinions on the draft financial plan submitted by the school head; d) collecting voluntary contributions from parents and spending them for purposes related to the statutory activity of the school.

When observing the activities of the parents' council in practice, we see that the most activities include the following specific fields:

- Adoption of documents previously prepared by the school management (the most important one is a preventive and educational program). Also, the parents' council reviews, among other things, the school's work schedule (including additional days free from didactic-educational activities), the school's statute, or the draft financial plan submitted by the school's director. Parents can submit their comments and changes to the presented documents and resolutions;

- Choosing an insurance company to take up student insurance in a given school year;

- Choosing a photographic studio that will be able to take occasional pictures and other services for pupils in a given year (e.g. calendars);

- Organizing fairs and other occasional events with the teachers, the proceeds of which are intended for charity purposes;

${ }^{7}$ J. Życiński, Bóg postmodernistów. Wielkie pytania filozofii we wspótczesnej krytyce moderny, Lublin 2001, p. 90.

8 Act of 14 December 2016 (Polish education law, DzU 2018 poz. 996) http:/ / prawo.sejm. gov.pl/isap.nsf/download.xsp/WDU20170000059/U/D20170059Lj.pdf [on-line: 20.08.2018]. 
- Reporting to the teachers and the school management the current problems which parents and students meet daily. Negotiating with the school management the rules for organising class tests and school tests (e.g. no more than two checks in a week) and rules for the implementation of housework. On the other hand, the management and teachers report to parents the problems that arise in the everyday functioning of their children and the activities of the school.

Making other resolutions, e.g. regarding important areas of pupils' functioning in the school (e.g. parents council in each school enacts the rules of using mobile phones on the school grounds because the national legislation does not make decisions on this matter).

There is also six type of parental involvement: ${ }^{9}$

1. Patenting - active parenting strategies and regular communication with school.

2. Communication - designing effective home-to-school and school-to-home communication methods.

3. Volunteering - recruiting volunteer parents to help in school in classes.

4. Learning at home - providing good information about character education.

5. Decision-making - including parents in decision-making activities to build a sense of ownership including being involved in character education.

6. Collaborating with the community - finding and using resources from the wider parent community to enrich school life.

Parents' cooperation with the school, which serves the above-defined moral development of pupils, is possible in almost all areas of the parents' council. The exception here is the choice by of companies entering school with their services, though the parents' council may consult the student self-government, which will have the opportunity to learn how to select the cheapest and the best service in a fair and transparent way. Directly parents and teachers involve students in the active implementation of moral values when they organise Christmas fairs, during which pupils sell artefacts they prepare in art lessons, while parents take care of proper setting of the whole event (cake and coffee sale, where profits provide additional financial resources). This practice, often encountered in Polish schools, allows students to make efforts to achieve noble goals (helping children from low-income families, supporting the rehabilitation of disabled students, planning for orphanages, or animal shelters, etc.). The parents' council allocates the funds obtained in this way. In

${ }^{9}$ J.L. Epstein, School/family/community partnerships: Caring for the children we share, Phi Delta Kappan, 1995. 76(9), p. 704-705; B. Lucas, The impact of parent engagement on learner success. A digest of research for teachers and parents. GEMS Education. https:/ / www.thehampshireschoolchelsea.co.uk/userfiles/files/For\%20Parents/Parental\%20Engagement/The-Impact-of-Parental-Engagement-on-Learner-Success613583.pdf, p.5 [on-line: 24.04.2019]. 
addition to promoting solidarity, such actions teach the value of cooperation and voluntary activities to all parties involved (students, teachers, parents).

The activities directly conducive to the maturing of moral youth include the involvement of students in volunteering and other activities whose characteristics are provided by the educational and preventive program (having such a program is the responsibility of each of nearly 30,000 schools in Poland). The program also includes the mission of the school, i.e., among others, activities for various values, whose significance for the general development of the moral human being and the whole society is indisputable. They are such values as love for the homeland (healthily understood patriotism) or care for one's health and personal hygiene. Being written in the preventive and educational program activities oriented around important values does not mean, unfortunately, that the school automatically implements them. Also, the involvement of parents in these activities does not necessarily always take place but depends on the parents' inventiveness and the ability to activate them by the headteacher and individual teachers. A loose relationship of legal provisions and declarations included in the program with their actual implementation can best be seen on the example of the statutory duty of each head of school. ${ }^{10}$ It is his/her duty to organise the way into school volunteers, associations and other organisations, especially scouts, whose statutory objectives include educational activity. The post-audit report of the Supreme Audit Office (the highest control body in Poland) shows that despite such an obligation, only every second audited school created conditions to operate for such organisations in its area. ${ }^{11}$

\section{Recommendation}

The basic form of the teacher-parent cooperation towards the virtue development is a good flow of information on the path between them. Direct contact will allow to get to know each other and understand each other's needs, expectations and problems. No other method will replace constant contact and talk. It is possible to formulate some general directives for the cooperation of teachers and parents on virtue development:

- the principle of positive co-operation: It says that an essential condition for effective parent-teacher cooperation is that he or she is volunteering to participate. The idea is that everyone is aware of the cooperation as well as the benefits associated with it;

10 Act of 14 December 2016, article 68, paragraph 1, point 9.

${ }^{11}$ Supreme Audit Office: NIK o współpracy szkół z rodzicami w realizacji zadań wychowawczych - informacje szczegółowe, https:/ / www.nik.gov.pl/plik/id,17004,vp,19563.pdf [on-line: 24.04.2019]. 
- partnership principle: Underlines the equal rights and duties of parents' tutors. The point is that none of the parties feels less valuable than the other, to create a kind of community whose members are equally involved in decision-making and are jointly responsible for implementing them;

- the principle of unity of interactions: Recalls the need for teachers and parents to achieve consistent goals in virtue development and educational work. In addition to meeting the objectives, it is also important to agree on the methods and forms of interaction.

- the principle of systematic cooperation: It shows the need for active and constant involvement in the performance of tasks initiated and organised during the cooperation of educators and parents;

The principles outlined above certainly do not encompass all those that should be guided by both educators and parents. Education is certainly the more efficient, the more it relies on the cooperation of teachers and parents. Both experience a greater or lesser need for relationships and collaboration for the benefit of children. Sometimes there is a distinct reluctance from both parties to deliberately organised cooperation. However, good cooperation is a condition for the harmonious development of the child, and that is the most important thing.

\section{Conclusion}

Despite several critical remarks in the text about the often-fictitious activities of the school and parents for the moral development of students, it should be noted that there is a platform created for parents' cooperation with the Polish schools. It is the parent's council, which among the many fields of its activity also undertakes activity focused on supporting the moral development of students. Mostly, thanks to the organising of joint charity campaigns by teachers, parents and their children. All students can take part in the preparation of various artefacts (Christmas decorations, cards, plush toys, etc.), in the purchase of assorted products (e.g. animal feed), or in providing services which frequently take place at school. The effort undertaken during these actions allows all parties to shape the need to act for the benefit of others, and thus allows them to develop morally.

\section{BIBLIOGRAPHY}

Act of 14 December 2016 (Polish education law, DzU 2018 poz. 996) http://prawo.sejm. gov.pl/isap.nsf/download.xsp/WDU20170000059/U/D20170059Lj.pdf [on-line: 20.08.2018]. 
Arthur J., Kristjánsson K., Harrison T., Sanderse W., Wright D., Teaching Character and Virtue in Schools, Routledge, London 2017.

Arthur J., Education with Character. The moral economy of schooling, RoutledgeFalmer, London 2013.

Bauman, Z., Obcy u naszych drzwi, Wydawnictwo Naukowe PWN, Warszawa 2016.

Berkowitz M.W. Democratic parenting, [in:] Parenting for Character: Five Experts, Five Practices, Ed. D. Streight, Portland: Council for Spiritual and Ethical Education Publications, 2008.

Berkowitz M.W., Grych J., Fostering goodness: Teaching parents to facilitate children's moral development, Journal of Moral Education, 1998, 27.

Berkowitz M.W., Bier M.C., McCauley B., Toward a Science of Character Education: Frameworks for Identifying and Implementing Effective Practices, Journal of Character Education, 2017, 13, 1 .

Bernasiewicz M., Worldview notions popularized by pop-culture. Identity, axiology and purposes of a contemporary teenager, [in:] Sociální pedagogika v kontextu životních etap člověka, Eds. M. Bargel, E. Janigová, E. Jarosz, M. Jůzl, Institut mezioborových studií, Brno 2013.

Borba M., Building moral intelligence: The seven essential virtues that teach kids to do the right thing, Jossey-Bass. Virtue focused practical guide for parenting for the character.

Charter of the Rights and Responsibilities of Parents in Europe, http://fapel.net/charter-rights-and-responsibilities-parents-europe/ [on-line:19.09.2018].

Desforges Ch., Abouchaar A., The impact of parental involvement, parental support and family education on pupil achievement and adjustment: a literature review, http://dera.ioe. ac.uk/6305/ [on-line: 10.08.2017].

Eco U., Pape, Satàn, aleppe. Kroniki płynnego społeczeństwa, Wydawnictwo Rebis, Poznań 2017.

Eldridge D., Parent Involvement: It's Worth the Effort, Young Children, 2001, 56(4).

Epstein J.L., School/family/community partnerships: Caring for the children we share, Phi Delta Kappan, 1995, 76(9).

Epstein J.L., School, Family, and Community Partnerships: Preparing Educators and Improving Schools, Second Edition, Westview Press, Boulder CO, 2011.

Graham-Clay S., Communicating with Parents: Strategies for Teachers, School Community Journal, 2005, 15(1).

Harrison T., Morris I., Ryan J., Teaching Character in the Primary Classroom, Sage, London 2016.

Hauer J., Educating for character and teachers' moral vitality, Journal of Research in Character Education, 2003, 1, 1.

Hill N.E., Taylor L.C., Parental school involvement and children's academic achievement: Pragmatics and issues, Current Directions in Psychological Science, 2004, 13.

Hughes J., Kwok O.-M., Influence of student-teacher and parent-teacher relationships on lower achieving readers' engagement and achievement in the primary grades, Journal of Educational Psychology, 2007, 99(1).

Kim E.M., Sheridana S.M., Kwon K., Koziola N., Parent beliefs and children's social-behavioral functioning: The mediating role of parent-teacher relationships, Journal of School Psychology, 2013, 51(2).

Kohlberg L., Mayer R., Development as the Aim of Education, Harvard Educational Review, 1972, 42(4).

Kraft M.A., Dougherty S., The Effect of Teacher-Family Communication on Student Engagement: Evidence from a Randomized Field Experiment, Journal of Research on Educational Effectiveness, 2013, 6(3).

Lasch Ch., The Culture of Narcissism. American Life in the Age of Diminishing Expectations, W.W. Norton \& Company, New York - London 1991. 
Lawrence-Lightfoot S., Building bridges from school to home, Instructor, 2004, 114(1).

Lickona T., How Parents and Schools can work together to raise Moral Children, Educational Leadership, 1988, 45(8).

Lickona T., Character Matters: How to Help Our Children Develop Good Judgment. Integrity, and Other Essential Virtues, Simon and Schuster, London 2004.

Lickona T., Educating for character: How our schools can teach respect and responsibility, Bantam Books, New York 2009.

Lucas B., The impact of parent engagement on learner success. A digest of research for teachers and parents. GEMS Education. https://www.thehampshireschoolchelsea.co.uk/userfiles/ files/For \% 20Parents/Parental\% 20Engagement/The-Impact-of-Parental-Engagement-on-Learner-Success613583.pdf [24.08.2018].

Łobocki M., Wspótdziałanie nauczycieli i rodziców w procesie wychowania, Wydawnictwo Nasza Księgarnia, Warszawa 1985.

Melosik Z., Kultura popularna i tożsamość młodzieży. W niewoli władzy i wolności, Oficyna Wydawnicza Impuls, Kraków 2013.

Muggleton D., Inside Subculture. The Postmodern Meaning of Style, Berg Publishers, Oxford - New York 2000.

Muggleton D., Weinzierl R. (Ed.), The Post-subcultures Reader, Berg Publishers, Oxford New York 2004.

Pepe A., Addimando L., Teacher-parent relationships: influence of gender and education on organizational parents' counterproductive behaviours, European Journal of Psychology of Education, 2014, 29(3).

Polhemus T., Style surfing: What to Wear in the 3rd Millennium, Thames and Hudson, London 1996.

Pomerantz E.M., Moorman E.A., Litwack S.D., The how, whom, and why of parents' involvement in children's academic lives: More is not always better, Review of Educational Research, 2007, 77.

Populus, A Framework for Character Education: Jubilee Centre Parents' Survey. http://jubileecentre.ac.uk/userfiles/jubileecentre/pdf/character-education/Populus\%20Parents\%20Study \%20-\%20short.pdf [24.08.2018].

Russ S., It's Unanimous: "Effective Character Education Is Not Quick or Superficial, and It Begins With Caring Relationships", Journal of Character Education, 2014, 10(1).

Sheridan S.M., Kratochwill T.R., Conjoint behavioral consultation: Promoting family-school connections and interventions, 2nd ed., Springe, New York 2008.

Sheridan S.M., Bovaird J.S., Glover T.A., Garbacz S.A., White A., Kwon K., A randomized trial examining the effects of conjoint behavioral consultation and the mediating role of parent-teacher relationship, School Psychology Review, 2012, 41(1).

Supreme Audit Office: NIK o wspótpracy szkót z rodzicami w realizacji zadań wychowawczych informacje szczegółowe, https://www.nik.gov.pl/plik/id,17004,vp,19563.pdf [on-line: 30.08.2018].

The Jubilee Centre for Character and Virtue: 'A Framework for Character Education' (2017) http://jubileecentre.ac.uk/userfiles/jubileecentre/pdf/other-centre-papers/ Framework.pdf) [24.08.2018].

Urban H., The nuts and bolts of effective teaching: 10 Things I Learned About Promoting High Standards in Both Academics and Character and Having Fun in the Process, Journal of Research in Character Education; 2007, 5(1).

Życiński J., Bóg postmodernistów. Wielkie pytania filozofii we wspótczesnej krytyce moderny, Wydawnictwo KUL, Lublin 2001. 